\title{
Effect of metformin therapy and dietary supplements on semen parameters in hyperinsulinaemic males
}

\author{
E. Bosman ${ }^{1 *}$, A. D. Esterhuizen ${ }^{1}$, F. A. Rodrigues ${ }^{1}$, P. J. Becker ${ }^{2} \&$ \\ W. A. Hoffmann ${ }^{3}$ \\ ${ }^{1}$ Medfem Clinic, Bryanston, South Africa; \\ ${ }^{2}$ Biostatistics Unit, Medical Research Council and Division of Clinical Epidemiology, University of Pretoria, \\ Pretoria, South Africa; \\ ${ }^{3}$ Department of Biomedical Sciences, Tshwane University of Technology, Pretoria, South Africa \\ * Correspondence \\ Edolene Bosman, Medfem Clinic, P.O. Box 2233, Cramerview 2060, South Africa. \\ Tel.: +27 115403440 ; \\ Fax: +27 114631875 ; \\ E-mail: ivflab@medfem.co.za
}

\section{Summary}

Previous reports indicated that hyperinsulinaemic men may exhibit a higher percentage of poorly compacted DNA in their spermatozoa and less success in an IVF programme (Andrologia, 45, 2003, 18; Andrologia, 2014, doi: 10.1111/and.12227). The aim of this study was to investigate the effect of metformin $\left(\right.$ Glucophage $\left.^{\circledR}\right)$ and antioxidant treatment $\left(\right.$ StaminoGro $\left.{ }^{\circledR}\right)$ on the semen parameters of hyperinsulinaemic men. Nineteen hyperinsulinaemic male patients were treated for 3 months with metformin alone (Group A), and fifteen patients used metformin in combination with the nutritional supplement (Group B). Combined data of the two groups (pre- and post-treatment) differ significantly regarding sperm morphology $(P=0.0003)$ and $\mathrm{CMA}_{3}(P<0.0001)$ values. The improvement in sperm morphology after treatment was similar for the two respective groups $(P<0.05)$. The morphological normal sperm forms increased from the mean percentage of 3.9 to $5.5 \%$ and from 4.2 to $5.5 \%$ for Group A and B respectively. Where a combination of metformin and the supplement were used (Group B), the combination treatment proved to be superior in obtaining enhanced chromatin packaging quality although not statistically significant $(P=0.5929)$ when compared with the metformin (Group A) group. The chromatin packaging quality in Group B improved with $10 \%$ while the improvement in Group A was approximately $8.3 \%$. Therefore, infertile hyperinsulinaemic men can benefit from metformin treatment and should be advised on the use of nutritional supplements with antioxidant properties.

\section{Keywords:}

$\mathrm{CMA}_{3}$; male hyperinsulinaemia; metformin; morphology; nutritional supplement

\section{Introduction}

Hyperinsulinaemia, which often occurs in obese men, has an inhibitory effect on normal spermatogenesis and can be linked to decreased male fertility (Du Plessis et al., 2010; Aboua et al., 2013). Insulin has an influence on the levels of sex-hormone-binding globulin (SHBG) 
and can contribute to low testosterone levels (Jensen et al., 2004; Tsai et al., 2004). Men with high insulin levels have a tendency to present with a higher percentage of poorly compacted sperm deoxyribonucleic acid (DNA) and lower pregnancy rates in an IVF programme (Bosman et al., 2013, 2014). Certain treatments such as metformin, a modified diet and exercise, can effectively control high insulin levels. Treatment and intervention of hyperinsulinaemic males can delay the onset and development of type 2 diabetes mellitus (DM) and possibly lead to improved semen parameters.

Sperm chromatin condensation plays a key role in male fertility, early embryonic growth and pregnancy results (Talebi et al., 2012). Chromomycin $\mathrm{A}_{3}\left(\mathrm{CMA}_{3}\right)$ is a guanine, cytosinespecific fluorochrome that competes with protamines for association with DNA (Lolis et al., 1996). Staining relates to the degree of protamination present in mature spermatozoa, and high $\mathrm{CMA}_{3}$ fluorescence is therefore a strong indicator of low protamination in the DNA of the spermatozoa (Manicardi et al., 1995). There is a meaningful relation between poor sperm chromatin packaging, sperm DNA damage, high levels of reactive oxygen species (ROS) and reproductive outcome (Esterhuizen et al., 2000; Duran et al., 2002; Evenson et al., 2002; Benchaib et al., 2003; Saleh et al., 2003). $\mathrm{CMA}_{3}$ values exceeding $40 \%$ (defective chromatin packaging) in semen samples have an adverse effect on IVF outcome (Esterhuizen et al., 2000).

Protamination is achieved when nicks are endogenously created to relieve the torsional stress of the DNA double helix. Once protamination is complete, the nicks completely disappear (Ward \& Coffey, 1991). The presence of endogenous nicks in ejaculated spermatozoa indicates incomplete maturation or protamination during spermiogenesis. Disruption of this critical process of chromatin packaging may result in persistence of endogenous nicks that would be, in turn, reflected as DNA damage. A higher percentage of DNA damage was found in infertile male patients compared to fertile men, and DNA damage strongly correlated with ROS levels (Moustafa et al., 2004). Immature spermatozoa additionally display a high percentage of alterations in chromatin packaging and produce excessive ROS (Bianchi et al., 1996; Manicardi et al., 1998) which in turn causes peroxidative damage to the plasma membrane, and impairment of sperm function (Mahfouz et al., 2010). High ROS concentrations result in oxidative stress, mitochondrial dysfunction, impaired sperm methylation, cellular damage, and in numerous cases, cell death (Loft et al., 2003; Tunc \& Tremellen, 2009).

The use of antioxidants such as vitamin $\mathrm{C}$ and $\mathrm{E}$ has been proved to be beneficial in the treatment of oxidative stress and DNA fragmentation (Koca et al., 2003). In this study, male patients with raised insulin levels were treated with metformin. The dosage of metformin depended on the fasting insulin results and varied from $500 \mathrm{mg}$ to $1500 \mathrm{mg}$ per night. Due to the added financial expense, patients were given the option to use StaminoGro ${ }^{\circledR}$ a nutritional supplement containing antioxidant components in combination with metformin. StaminoGro ${ }^{\circledR}$ was taken 3 months prior to the commencement of assisted reproductive procedures. The treatment was initialised by taking one tablet at night for 1 week, followed by taking two tablets after supper for three nights, then three tablets for the consecutive three night and thereafter four tablets were taken up until conception. The mineral and vitamin contents of the supplement are summarised in Table 1. The aim of this study was to investigate the effect of metformin and an antioxidant supplement on the semen parameters of hyperinsulinaemic men. 
Table 1. Mineral and vitamin contents of StaminoGro ${ }^{\circledR}$ supplement (Georen, 2013)

\begin{tabular}{|c|c|c|c|c|}
\hline $\begin{array}{l}\text { Amino } \\
\text { acids }\end{array}$ & Antioxidants & B-complex vitamins & $\begin{array}{c}\text { Calcium and } \\
\text { vitamin D } \\
\end{array}$ & $\begin{array}{c}\text { Other vitamins and } \\
\text { minerals }\end{array}$ \\
\hline $\begin{array}{l}\text { Glycine } \\
\text { L-arginine } \\
\text { L- } \\
\text { glutamine } \\
\text { L-lysine } \\
\text { L-omithine }\end{array}$ & $\begin{array}{l}\text { Beta-carotene } \\
(10 \%) \\
\text { Lipoic acid } \\
\text { Vitamin C } \\
\text { Vitamin E } \\
\text { Selenium }\end{array}$ & $\begin{array}{l}\text { Folic acid } \\
\text { Vitamin B1 - thiamine } \\
\text { Vitamin B2 - riboflavine } \\
\text { Vitamin B3 - nicotinamide } \\
\text { Vitamin B5 - pantothenic acid } \\
\text { Vitamin B6 - pyridoxine } \\
\text { Vitamin B12 - derived from } \\
\text { methylcobalamin }\end{array}$ & $\begin{array}{l}\text { Elemental } \\
\text { Calcium } \\
\text { Vitamin D3 }\end{array}$ & $\begin{array}{l}\text { Biotin } \\
\text { Choline bitartrate } \\
\text { Copper } \\
\text { Magnesium } \\
\text { Manganese } \\
\text { Zinc }\end{array}$ \\
\hline
\end{tabular}

\section{Materials and methods}

\section{Patient selection}

Patients scheduled for semen analysis at Medfem Clinic received instruction to sexually abstain for 3 days prior to sperm testing. Fasting insulin levels were determined with a blood test on the morning of semen analysis. Patients were instructed to fast from $22 \mathrm{H} 00$ the night before testing. Patients were requested to provide information regarding their weight, height and waist size. Hyperinsulinaemic males with fasting insulin levels above $9.2 \mu \mathrm{IU} \mathrm{ml}{ }^{-1}$ were followed up and treated with Glucophage ${ }^{\circledR}$ (metformin) and given the option to use the supplement StaminoGro ${ }^{\circledR}$ (Georen Pharmacuticals PTY LTD, Fontainebleau, South Africa) as part of the treatment. Metformin has been established as the first-line treatment option in the management of type $2 \mathrm{DM}$ (Mkele, 2013). The minimum effective dose for metformin is $500 \mathrm{mg}$ day $^{-1}$ with an optimum dose of $2000 \mathrm{mg}$ day $^{-1}$. Metformin is taken with meals to help reduce stomach or bowel side effects that may occur during the first few weeks of treatment. Patients were prescribed to start with a dose of $500 \mathrm{mg}$ once a day with the evening meal. If needed, the dose was increased until the blood sugar was controlled. The dosages for StaminoGro ${ }^{\circledR}$ are discussed above. Patients who adhered to the prescribed drugs and dosages were retested 3 months after treatment. The routine semen analysis was repeated and data noted. Males who presented with varicocele or hyperthyroidism were not included in the study.

\section{Routine semen analysis}

Samples were assessed according to the WHO manual for light microscopic semen analysis, and values were recorded for sperm count, motility and viability (WHO, 2010). Normal sperm morphology assessment was based on the Tygerberg's strict criteria (Menkveld et al., 1990).

\section{$\mathrm{CMA}_{3}$}

Smears were made of the semen samples and left to air-dry before they were fixed in three parts methanol and one part acetic acid (Carnoy's solution) for 20 min at $4{ }^{\circ} \mathrm{C}$. $\mathrm{CMA}_{3}$ staining 
was performed according to the method described by Esterhuizen et al. (2000). A Nikon fluorescent microscope with a 460-nm filter was used to score at least 200 spermatozoa using the 100x magnification, under oil. Spermatozoa with poor chromatin packaging, stain bright yellow, were expressed as the percentage of sperm with immaturely packaged DNA. Nonreacted spermatozoa appear faintly yellowish green under the fluorescence microscope and were counted as mature forms (Fig. 1).

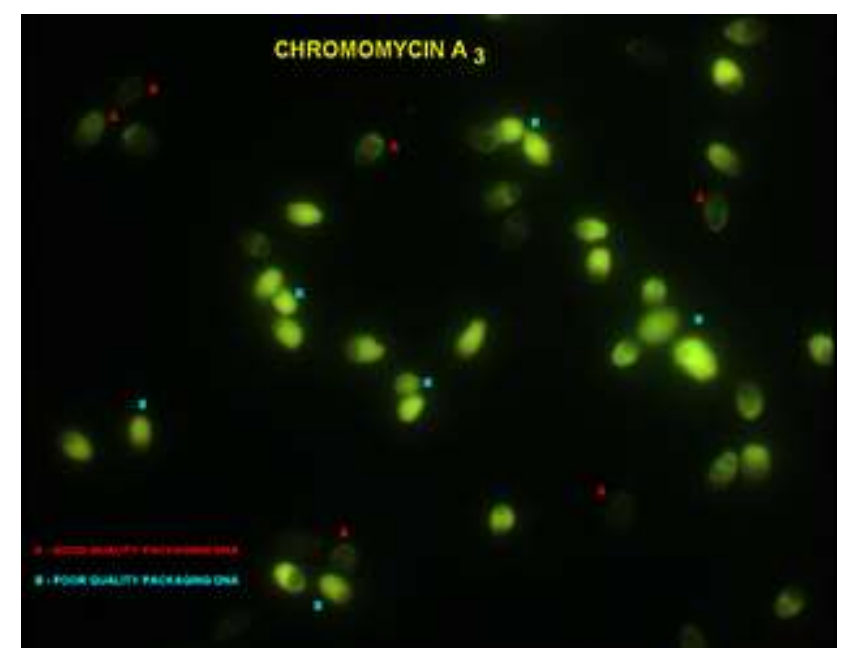

Figure 1. Spermatozoa with poor chromatin package showing bright yellow under fluorescence $(100 \times$ magnification). $\mathrm{A}=$ Good-quality DNA packaging in the sperm head. $\mathrm{B}=$ Poor-quality DNA packaging in the sperm head.

\section{Statistical analysis}

Treatment groups were compared with respect to change in semen parameters from pre- to post-treatment. An analysis of variance for ranks was employed for the ranks of the pretreatment values. Testing was performed at the 0.05 level of significance with the use of Stata Statistical Software: Release 10, College Station, TX, StataCorp.

\section{Results}

A total of 34 patients met the inclusion criteria for hyperinsulinaemia after initial testing and semen analysis. Nineteen patients were treated with the supplement alone (Group A), and fifteen patients used metformin in combination with the supplement (Group B). The ages of the males ranged between 33 and 45 years. The fasting insulin levels for the groups ranged from 10.2 to $38.3 \mu \mathrm{IU} \mathrm{ml}{ }^{-1}$ with an average of $16.9 \pm 5.3 \mu \mathrm{IU} \mathrm{ml}^{-1}$. Group A had an average fasting insulin of $16.4 \pm 5.8 \mu \mathrm{IU} \mathrm{ml}^{-1}$ and Group B of $15.7 \pm 6.6 \mu \mathrm{IU} \mathrm{ml}^{-1}$.

The pre- and post-treatment semen parameters for the two different treatment groups are presented in Table 2. 
Table 2. Pre- and post-treatment sperm parameters of Group A and Group B

\begin{tabular}{|c|c|c|c|c|}
\hline \multirow[b]{2}{*}{ Sperm parameters } & \multicolumn{2}{|c|}{ Group A $(n=19)$} & \multicolumn{2}{|c|}{ Group B $(n=15)$} \\
\hline & $\begin{array}{c}\text { Pre-treatment } \\
(\text { mean } \pm \text { SD })\end{array}$ & $\begin{array}{c}\begin{array}{c}\text { Post-treatment } \\
(\text { mean } \pm \text { SD })\end{array} \\
\end{array}$ & $\begin{array}{c}\text { Pre-treatment } \\
(\text { mean } \pm \text { SD) }\end{array}$ & $\begin{array}{c}\begin{array}{c}\text { Post-treatment } \\
(\text { mean } \pm \text { SD })\end{array} \\
\end{array}$ \\
\hline \multicolumn{5}{|c|}{$\begin{array}{l}\text { 1. Statistically significant difference between pre- and post-treatment values. } \\
\text { 2. }{ }^{\mathrm{a}} P=0.002 ;{ }^{\mathrm{b}} P=0.006 ;{ }^{\mathrm{c}} P=0.040 ;{ }^{\mathrm{d}} P=0.016 \text {. }\end{array}$} \\
\hline $\begin{array}{l}\text { Sperm concentration } \\
\left(\times 10^{6} \mathrm{ml}^{-1}\right)\end{array}$ & $32.6 \pm 21.2$ & $42.7 \pm 32.9$ & $36.0 \pm 32.3$ & $34.0 \pm 18.4$ \\
\hline$\%$ Motility & $53.9 \pm 16.3$ & $49.3 \pm 11.9$ & $53.1 \pm 11.5$ & $53.0 \pm 11.5$ \\
\hline$\%$ Vitality & $62.3 \pm 13.7$ & $59.3 \pm 10.6$ & $61.3 \pm 9.6$ & $63.1 \pm 11.7$ \\
\hline $\begin{array}{l}\% \text { Normal } \\
\text { morphology }\end{array}$ & $3.9 \pm 2.2^{\mathrm{a}}$ & $5.5 \pm 2.9^{\mathrm{a}}$ & $4.2 \pm 1.6^{\mathrm{b}}$ & $5.5 \pm 2.8^{\mathrm{b}}$ \\
\hline $\begin{array}{l}\mathrm{CMA}_{3}(\% \text { immature } \\
\text { forms })\end{array}$ & $57.7 \pm 13.8^{\mathrm{c}}$ & $50.5 \pm 10.9^{c}$ & $64.3 \pm 11.6^{\mathrm{d}}$ & $52.3 \pm 6.8^{\mathrm{d}}$ \\
\hline
\end{tabular}

A comparison of the findings for Group A and Group B indicates that the improvement in sperm morphology was similar for the two groups. The mean percentage normal morphology of the metformin group (Group A) increased from 3.9 to 5.5\% normal forms, while the group that used a combination of metformin and the supplement (Group B) improved from 4.2 to $5.5 \%$. The change in $\mathrm{CMA}_{3}$ levels was higher in Group B than in Group A. The chromatin packaging quality in Group B improved with $~ 12 \%$ from 64.2 to $52.3 \%$, and from 57.3 to $50.5 \%$ in Group A. However, when these values were statistically adjusted for baseline variables, the changes were $10 \%$ and $8.3 \%$, respectively, and not statistically significant $(P=0.5929)$.

Combining the data of Groups A and B demonstrated that there was no statistically significant difference between the mean pre-treatment versus post-treatment sperm counts, percentage motile sperm or sperm vitality (Table 3 ). However, statistically significant increases were found for sperm morphology (\% normal forms) and $\mathrm{CMA}_{3}$ values after treatment $(P=0.0003 ; P<0.0001)$ (Table 3).

Table 3. Pre- and post-treatment sperm parameters of the hyperinsulinaemic group $(n=34)$

\begin{tabular}{|c|c|c|c|}
\hline Semen parameter & Pre-treatment $($ mean \pm SD) & Post-treatment $($ mean \pm SD) & $P$-value \\
\hline \multicolumn{4}{|l|}{$1 . \quad a$} \\
\hline \multicolumn{4}{|c|}{ Statistically significant difference. } \\
\hline Sperm concentration $\left(\times 10^{6} \mathrm{ml}^{-1}\right)$ & $34.1 \pm 26.2$ & $38.8 \pm 27.4$ & 0.3099 \\
\hline$\%$ Motility & $53.6 \pm 14.3$ & $50.9 \pm 11.7$ & 0.2287 \\
\hline$\%$ Vitality & $61.8 \pm 11.8$ & $61.0 \pm 11.1$ & 0.6161 \\
\hline$\%$ Normal morphology & $4.1 \pm 1.9 \mathrm{a}$ & $5.5 \pm 2.8 \mathrm{a}$ & 0.0003 \\
\hline$\%$ Immature forms $\left(\mathrm{CMA}_{3}\right)$ & $60.4 \pm 13.2 \mathrm{a}$ & $51.3 \pm 9.2 \mathrm{a}$ & $<0.0001$ \\
\hline
\end{tabular}

\section{Discussion}

There is a growing body of evidence that elucidates the important role of sperm DNA damage in male infertility and the clinical relevance thereof in the outcome in ART. 
The challenge is to understand the various clinical applications of the multifactorial impact of sperm chromatin integrity, as well as the approaches to improve sperm chromatin integrity (Hekmatdoost et al., 2009). Various methods to evaluate sperm chromatin integrity have been developed, such as acidic aniline blue, toluidine blue, $\mathrm{CMA}_{3}$, sperm chromatin dispersion and comet assay (Kim et al., 2013; Simon et al., 2014). In comparison with all the alternative chromatin integrity tests available, the $\mathrm{CMA}_{3}$ assay is an inexpensive and straightforward test and does not require expensive equipment such as flow cytometry (Talebi et al., 2012).

Sperm chromatin becomes more compacted during the process of spermatogenesis, when histones are replaced firstly by testis-specific nuclear proteins, then by transitional proteins and finally by protamines. As such, abnormalities that occur during the expression of spermspecific nucleoproteins have an influence on sperm chromatin structure and may cause male infertility (Talebi et al., 2012). Sperm DNA integrity has been associated with decreased embryo quality and an increase in miscarriage rates in assisted reproduction (Morris et al., 2002). According to Paldi (2003), normal chromatin structure is critical for correct methylation of imprinted genes. DNA methylation and histone modifications are the two major mechanisms involved in genetic imprinting in humans (Kobayashi et al., 2007; Manipalviratn et al., 2009). The primary role of the sperm protamines is to ensure normal sperm chromatin structure. Aoki et al. (2005) suggested that protamine and chromatin structural defects may leave sperm susceptible to improper imprinting patterns in critical genes. Some concern has been raised over a possible relation between assisted reproductive technologies (ART) and genomic imprinting disorders (Lawrence \& Moley, 2008).

Spermatogenesis is an intricate process in which an abundance of nutritional supplies is crucial during spermatogenesis. Antioxidant supplementation is one of the basic strategies that can be easily employed to enhance DNA integrity (Sharma et al., 2004). Tunc \& Tremellen (2009) reported that 3 months of supplementation with antioxidant supplement resulted in a significant decrease in seminal ROS and sperm DNA fragmentation of infertile men, while increasing sperm DNA methylation. Similarly, the use of the mineral and vitamin supplement in combination with metformin in the current study resulted in a greater improvement of DNA integrity than the use of metformin alone.

Hyperglycaemia causes a high level of oxidative stress, with excess production of ROS and a decreased efficiency of antioxidant systems (Agbaje et al., 2007; Mangoli et al., 2013). To our knowledge, this study is the first to address the influence of hyperinsulinaemia on male infertility and the effect of metformin treatment on semen parameters. The seemingly negative effect of DM on sperm parameters has previously been raised by other researchers (La Vignera et al., 2011; Mangoli et al., 2013), but the actual effect of hyperinsulinaemia remained unknown. High insulin levels and the unstable glycemic state may have a similar increase in ROS production as reported in DM cases (Agbaje et al., 2007; Mangoli et al., 2013). Antioxidants such as vitamin C, E and zinc present in supplements, stabilise cell membranes and protect cells against ROS. Various studies have indicated that sperm quality is enhanced by zinc, selenium, folate and vitamin supplementation. Selenium plays an active role in sperm DNA compaction (Hadaszadeh \& Beggs, 2006). In addition, zinc deficiencies in men can inhibit angiotensin-converting enzyme activity in Leydig cells, which consequently result in testosterone depression and the impediment of spermatogenesis (Liu et al., 2009). However, a minimum concentration of ROS is needed in many organs, especially the reproductive organs, as ROS is critical in regulating the onset of hyperactivation, spermatozoa capacitation and acrosome reaction. Thus, excessive intake of 
antioxidants may actually result in impaired sperm function by inhibiting the necessary ROS (Bolle et al., 2002).

In a previous study, it was reported previously that hyperinsulinaemic male patients had a significantly lower IVF pregnancy rate of $31.8 \%$ when compared to the $57.9 \%$ pregnancy rate, of a normo-insulinaemic male group (Bosman et al., 2014). Early diagnosis and treatment of male hyperinsulinaemia prior to ART is advised as improved morphology and $\mathrm{CMA}_{3}$ values can be beneficial to pregnancy outcome. The significant improvement of the $\mathrm{CMA}_{3}$ values seen in the supplement treatment group suggests that ROS has a detrimental effect on the semen parameters of hyperinsulinaemic men. The importance of the current study is demonstrated by the significantly positive effect of metformin/supplement treatment on sperm morphology and $\mathrm{CMA}_{3}$ values. Another valuable contribution of this study is the effective assessment of hyperinsulinaemia on semen quality and the treatment thereof prior to the onset of diabetes and the deterioration of semen parameters. Antioxidant treatment with supplements should be a standard regime for male infertility patients, while hyperinsulinaemic men can benefit from additional metformin treatment.

\section{References}

Aboua G, Oguntibeju OO, Du Plessis S (2013) Handbook of In Vitro Fertilization, 2nd edn. Trounson AO, Gardner DK (eds). CRC Press, Boca Raton, FL, USA. http://dx.doi.org/10.5772/47838.

Agbaje IM, Rogers DA, McVicar CM, McClure N, Atkinson AB, Mallidis C, Lewis SEM (2007) Insulin dependent diabetes mellitus: implications for male reproductive function. Hum Reprod 22:1871-1877.

Aoki VW, Liu L, Carrell TC (2005) Identification and evaluation of a novel sperm protamine abnormality in a population of infertile males. Hum Reprod 20:1298-1306.

Benchaib M, Braun V, Lornage J, Hadj S, Salle S, Lejeune H, Guerin JF (2003) Sperm DNA fragmentation decreases the pregnancy rate in a reproductive assisted technique. Hum Reprod 18:1023-1028.

Bianchi PG, Manicardi GC, Urner F, Campana A, Sakkas D (1996) Chromatin packaging and morphology in ejaculated human spermatozoa: evidence of hidden anomalies in normal spermatozoa. Mol Hum Reprod 2:139-144.

Bolle P, Evandri MG, Saso L (2002) The controversial efficacy of vitamin E for human male infertility. Contraception 6:313-315.

Bosman E, Esterhuizen AD, Rodrigues FA, Becker PJ, Hoffmann WA (2013) Prevalence of hyperinsulinaemia among normozoospermic donors at Medfem Clinic, South Africa. Andrologia 45:18-25.

Bosman E, Esterhuizen AD, Rodrigues FA, Becker PJ, Hoffmann WA (2014) Influence of male hyperinsulinaemia on IVF outcome. Andrologia. DOI: 10.1111/and.12227.

Du Plessis SS, Cabler S, McAlister DA, Sabanegh E, Agarwal A (2010) The effect of obesity on sperm disorders and male infertility. Nat Rev Urol 7:153-161. 
Duran EH, Morshedi M, Taylor S, Oehninger S (2002) DNA quality predicts intrauterine insemination outcome: a prospective cohort study. Hum Reprod 12:3122-3128.

Esterhuizen AD, Franken DR, Lourens JGH, Prinsloo E, van Rooyen LH (2000) Sperm chromatin packaging as an indicator of in-vitro fertilization rates. Hum Reprod 15:657-661.

Evenson D, Larson KL, Jost L (2002) Sperm chromatin structure assay: its clinical use for detecting sperm DNA fragmentation in male infertility and comparisons with other techniques. J Androl 23:25-43.

Georen (2013) Product Insert. GeorenPharmaceuticals (Pty) Ltd, Fontainebleau, South Africa. www.georen.co.za/georen/index.php/2013-11-25.../staminogro.

Hadaszadeh BM, Beggs AH (2006) Selenoproteins and their impact on human health through diverse physiological pathways. Physiology (Bethesda) 21:307-315.

Hekmatdoost A, Lakpour N, Sadeghi MR (2009) Sperm chromatin integrity: etiologies and mechanisms of abnormality, assays, clinical importance, preventing and repairing damage. Avicenna J Med Biotechnol 1:147-160.

Jensen TK, Andersson A, Jørgensen N, Andersen A, Carlsen E, Petersen JH, Skakkebæk NE (2004) Body mass index in relation to semen quality and reproductive hormones among 1,558 Danish men. Fertil Steril 82:863-870.

Kim HS, Kang MJ, Kim SA, Oh SK, Kim H, Ku SY, Kim SH, Moon SY, Choi YM (2013) The utility of sperm DNA damage assay using toluidine blue and aniline blue staining in routine semen analysis. Clin Exp Reprod Med 40:23-28.

Kobayashi H, Sato A, Otsu E (2007) Aberrant DNA methylation of imprinted loci in sperm from oligospermic patients. Hum Mol Genet 16:2542-2551.

Koca Y, Ozdal OL, Celik M, Unal S, Balaban N (2003) Antioxidant activity of seminal plasma in fertile and infertile men. Arch Androl 49:355-359.

La Vignera S, Condorelli R, Vicari E, D'Agata R, Calogera AE (2011) Diabetes and sperm parameters: a brief review. J Androl 33:145-153.

Lawrence LT, Moley KH (2008) Epigenetics and assisted reproductive technologies: human imprinting syndromes. Semin Reprod Med 26:143-152.

Liu DY, Sie B, Liu ML, Agresta F, Baker HWG (2009) Relationship between seminal plasma zinc concentration and spermatozoa-zona pellucida binding and the ZP-induced acrosome reaction in sub fertile men. Asian J Androl 11:499-507.

Loft S, Kold-Jensen T, Hjolland NH, Giwercman A, Gyllemborg J, Ernst E, Olsen J, Scheike T, Poulsen HE, Bonde JP (2003) Oxidative DNA damage in human sperm influences time to pregnancy. Hum Reprod 18:1265-1272. 
Lolis D, Georgiou I, Surrou M, Zikopoulos K, Konstantelli M, Messinis I (1996) Chromomycin A3-staining as an indicator of protamine deficiency and fertilization. Int $J$ Androl 19:23-27.

Mahfouz R, Sharma R, Thiyagarajan A, Kale V, Gupta S, Sabanegh E, Agarwal A (2010) Semen characteristics and sperm DNA fragmentation in infertile men with low and high levels of seminal reactive oxygen species. Fertil Steril 94:2141-2146.

Mangoli E, Talebi AR, Anvari M, Pourentezari M (2013) Effects of experimentally-induced diabetes on sperm parameters and chromatin quality in mice. Iran J Reprod Med 11:53-60.

Manicardi GC, Bianchi PG, Pantano S, Azzoni P, Bizzaro D, Bianchi U, Sakkas D (1995) Presence of endogenous nicks in DNA of ejaculated human spermatozoa and its relationship to chromomycin $\mathrm{A}_{3}$ accessibility. Biol Reprod 52:864-867.

Manicardi GC, Tombacco A, Bizzaro D, Bianchi U, Bianchi PG, Sakkas D (1998) DNA strand breaks in ejaculated human spermatozoa: a comparison of susceptibility to the nick translation and terminal transferase assays. Histochem J 30:33-39.

Manipalviratn S, DeCherney A, Segars J (2009) Imprinting disorders and assisted reproductive technology. Fertil Steril 91:305-315.

Menkveld R, Stander FSH, Kotze TJvW, Kruger TF, van Zyl JA (1990) The evaluation of morphological characteristics of human spermatozoa according to stricter criteria. Hum Reprod 5:586-592.

Mkele G (2013) A review of metformin and its place in the diabetes guidelines. S Afr Pharm $J$ 80:2022.

Morris ID, Ilott S, Dixon L, Brison DR (2002) The spectrum of DNA damage in human sperm assessed by single cell gel electrophoresis (Comet assay) and its relationship to fertilization and embryo development. Hum Reprod 17:990-998.

Moustafa MH, Sharma RK, Thornton J, Mascha E, Abdel-Hafez MA, Thomas AJ, Agarwal A (2004) Relationship between ROS production, apoptosis and DNA denaturation in spermatozoa from patients examined for infertility. Hum Reprod 19:129-138.

Paldi A (2003) Genomic imprinting: could the chromatin structure be the driving force? Curr Top Dev Biol 53:115-138.

Saleh RA, Agarwal A, Nada EA, El-Tonsy MH, Sharma RK, Meyer A, Nelson DR, Thomas AJ (2003) Negative effects of increased sperm DNA damage in relation to seminal oxidative stress in men with idiopathic and male factor infertility. Fertil Steril 79(Suppl 3):597-605.

Sharma RK, Said T, Agarwal A (2004) Sperm DNA damage and its clinical relevance in assessing reproductive outcome. Asian J Androl 6:139-148.

Simon L, Liu L, Murphy K, Ge S, Hotaling J, Aston KI, Emery B, Carrell DT (2014) Comparative analysis of three sperm DNA damage assays and sperm nuclear protein content in couples undergoing assisted reproduction treatment. Hum Reprod 29:904-917. 
StataCorp (2007) Statcorp Stata Statistical Software: Release 10, College Station, TX.

Talebi AR, Vahidi S, Aflatoonian A, Ghasemi N, Ghasemzadeh J, Firoozabadi RD, Moein MR (2012) Cytochemical evaluation of sperm chromatin and DNA integrity in couples with unexplained recurrent spontaneous abortions. J Androl 22(Suppl):462-470.

Tsai EC, Matsumoto AM, Fujimotot WY, Boyko EJ (2004) Association of bioavailable free, and total testosterone with insulin resistance: influence of sex hormone-binding globulin and body fat. Diabetes Care 27:861-868.

Tunc O, Tremellen K (2009) Oxidative DNA damage impairs global sperm DNA methylation in infertile men. J Assist Reprod Genet 26:537-544.

Ward WS, Coffey DS (1991) DNA packaging and organization in mammalian spermatozoa comparison with somatic cells. Biol Reprod 44:569-574.

World Health Organization (2010) WHO Laboratory Manual for the Examination and Processing of Human Semen, 5th edn. World Health Organization, Geneva. 